\title{
Seasonal Abundance of and Estimated Food Consumption by Cetaceans in Icelandic and Adjacent Waters
}

\author{
Jóhann Sigurjónsson and Gísli A. Víkingsson \\ Marine Research Institute, P. O. Box 1390, Skúlagata 4, 121 Reykjavík, Iceland
}

\begin{abstract}
The consumption of fish, cephalopods and planktonic crustaceans by cetaceans in Icelandic and adjacent waters was estimated. The estimates were based on (i) abundance estimates from recent sighting surveys (NASS-87,89,95); (ii) seasonal variation in abundance estimated from sightings and/or catch data from whaling vessels; and (iii) consumption rates calculated from the estimated biomass of cetaceans in the area throughout the year. A large number of assumptions had to be made, and these calculations were mainly intended to give an idea of the possible magnitude of consumption as well as to be a guidance for further research in this field. The total food consumption was estimated as 6.3 million tons in a smaller area defined as Icelandic and adjacent waters, and 8.8 million tons in the larger area north of $60^{\circ} \mathrm{N}$. Considering total consumption, fin whales (Balaenoptera physalus) and minke whales (B. acutorostrata) were the largest consumers in the area, followed by long-finned pilot whales (Globicephala melas) and northern bottlenose whales (Hyperoodon ampullatus). Crustaceans comprise around 50\% of the total consumption within the study area while finfish and cephalopods comprised $27 \%$ and $22 \%$, respectively, in the large area. Minke whales were the largest consumers of finfish, consuming more than 1 million tons of fish in Icelandic and adjacent waters.
\end{abstract}

Key words: feeding, food, Iceland area, whales

\section{Introduction}

The ecological role of cetaceans, particularly their potential interactions with fisheries is often debated by laymen and scientists. In recent years a number of studies have addressed this question, particularly with respect to the drastic changes that took place in the Southern Ocean subsequent to the collapse of most large baleen whale stocks during this century (e.g. Laws, 1977, 1985; Hinga, 1979). Several studies have examined the situation in other ocean areas, such as off the eastern coast of North America where cetaceans have been investigated with respect to their role in the ecosytem (e.g. Scott et al., MS 1983; Overholtz et al., 1991; Kenney et al., 1997). These studies have been centered around the question of total biomass of cetaceans and their estimated predation. A series of studies have dealt with theoretical aspects of cetacean bioenergetics and food requirements (Sergeant, 1969; Kawamura, 1974; Brodie, 1975; Mitchell, 1975; Lockyer, 1981a, 1987a, 1987b; Lavigne et al., 1986; Innes et al., 1987; Víkingsson et al., 1988; Víkingsson, 1990, 1995, 1997; Ichii and Kato, 1991), which have formed an important basis for further calcula- tions of cetacean predation. Recent studies in Norway have further developed this work as a part of extensive research into the role of marine mammals in Norwegian waters (e.g. Markussen et al., 1992; Folkow and Blix, 1992; Haug et al., 1996; Nordøy et al., 1995).

Recently, studies have been initiated by the Marine Research Institute (MRI), Reykjavík, with the aim of understanding the ecological role of cetaceans in Icelandic and adjacent waters within a broad multi-species context. While the long-term aim of the research program is to make predictions concerning the dynamic relationship between the different species, it soon became evident that very limited knowledge on the current consumption by whales in these waters was available. This was partly due to various difficulties in estimating the food selection and energy requirements of the different species of whales, but mainly because of the absence of data on absolute and seasonal abundance of each species. In 1987, 1989 and 1995 the MRI undertook extensive whale sightings surveys in Icelandic and adjacent waters as a part of joint international efforts (North Atlantic Sightings Surveys, 
NASS-87, NASS-89 and NASS-95) of several North Atlantic nations (see Sigurjónsson et al., 1989; Sigurjónsson et al., 1991; Sigurjónsson et al., MS 1996). The results of these surveys have greatly improved our knowledge on abundance of the many species of whales that frequent high latitude North Atlantic waters during the summer season.

In this paper estimates of cetacean prey consumption in Icelandic and adjacent waters are reported. These results are mainly intended to serve as a basis for more in-depth analysis, and as a guide for planning future research. Our results were derived from abundance estimates based on the NASS surveys, supplemented by sightings data on seasonal occurrence from whaling vessels west and southwest of Iceland during 1979-85 and Icelandic catch data for large whales (1948-89) and minke whales (Balaenoptera acutorostrata) (1973-85). Estimated consumption rates for each species were based on published relationships of ingestion rates and body weight, with the latter calculated from Icelandic catch data whenever possible. Finally, estimates of consumption of specific prey were based on our observations of food selection where possible, but to a large degree upon published records of food selection by cetaceans in other ocean areas.

\section{Material and Methods}

\section{Estimates of whale abundance}

The NASS surveys were conducted during 24 June-28 July 1987, 10 July-13 August 1989 (with main effort in the latter half of the period) and 22 June-4 August 1995, respectively. Although the survey design and the survey blocks already analysed for the purpose of abundance estimation are not strictly the same as would suit our study on whale predation in Icelandic waters (continental shelf or 200 naut. miles EEZ around Iceland), we have tried to choose the relevant survey blocks for our purposes. Firstly, we consider the waters roughly north of $60^{\circ} \mathrm{N}$, surveyed by Iceland in the years 1987, 1989 and 1995 (Fig. 1), i.e. the Irminger Sea, the waters north and northeast of Iceland towards Jan Mayen and the Iceland Basin towards the Faroe Islands. Secondly, we consider the same areas, but leaving out the southwestern part of the Irminger Sea for the purposes of evaluating the proper "Icelandic and adjacent waters" area (Fig. $1)$.

For most species we used abundance estimates for the relevant survey blocks, directly or indirectly, from published sources or manuscripts based on the NASS surveys (see Table 1), calculated according to accepted line-transect methodology (see Hiby and Hammond, 1989) as follows:

- fin whale (Balaenoptera physalus) Borchers and Burt, MS 1997; NAMMCO, 1997

- sei whale (B. borealis) - Cattanach et al. (1993); IWC (1993)

- minke whale - Borchers et al., MS 1997; NAMMCO, 1997

- long-finned pilot whale (Globicephala melas) - Buckland et al. ,1993

- blue whale (Balaenoptera musculus) Sigurjónsson et al., 1991

- humpback whale (Megaptera novaeangliae) - Gunnlaugsson and Sigurjónsson, 1990

- sperm whale (Physeter macrocephalus) Gunnlaugsson and Sigurjónsson, 1990, Sigurjónsson et al., 1991

- northern bottlenose whale (Hyperoodon ampullatus) - Sigurjónsson et al., 1991

- killer whale (Orcinus orca) - Gunnlaugsson and Sigurjónsson, 1990.

In addition we calculated new or revised estimates for several species. The published estimates for sperm whales were corrected for diving behaviour using factors of 2.11 and 9.07, respectively. These corrections were done according to the method of Gunnlaugsson and Sigurjónsson (1990), assuming mean dive times of 10 min for sperm whales (Lockyer, 1977) and $33.1 \mathrm{~min}$ for northern bottlenose whales (Benjaminsen and Christensen, 1979). Blue and sperm whale abundance for 1989 was calculated from data published in Sigurjónsson et al. $(1989,1991)$ using the 1987 pependicular distance data (Gunnlaugsson and Sigurjónsson, 1990). For the 1989 estimates of blue and sei whales, data from 1987 for one survey block which was not surveyed in 1989 were added, assuming similar distribution of these species in 1987 and 1989.

We also estimated approximate abundance of white-beaked dolphin (Lagenorhynchus albirostris ), Atlantic white-sided dolphin (L. acutus), unidentified dolphins and harbour porpoise (Phocoena phocoena) from the NASS-87 survey data by:

$$
N=n * s * A /(L * 2 W)
$$

where $N$ is abundance in a survey block, $n$ is the number of schools sighted, $s$ is mean school size, 


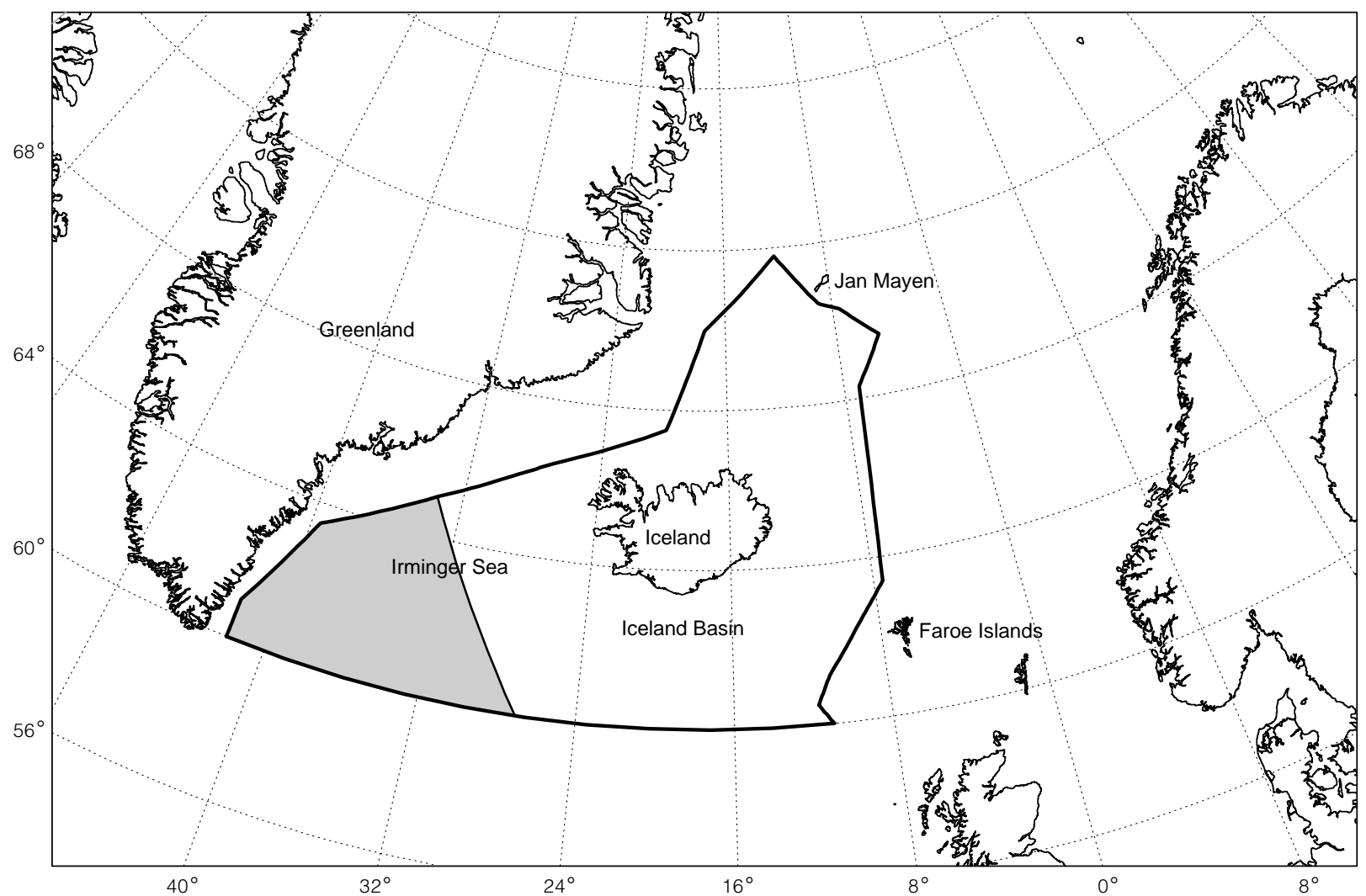

Fig. 1. Area of the NASS surveys, used in the analysis. The shaded area indicates difference between the two areas, "Iceland and adjacent waters" and larger "north of $60^{\circ} \mathrm{N}$ " includes the former plus the shaded area.

$A$ is the area of the block, $L$ is the length of the survey track, and $w$ is the effective search halfwidth. For dolphins, $w$ was assumed to be 0.8 naut. miles, which is probably in the upper range for these species. No stratification for school sizes were made and the estimates should only be taken as rough approximations subject for further analysis. For harbour porpoise we used $w=0.1105$ naut. miles (Bjørge and Øien, 1995) and a correction factor for $g$ (0) of 0.7 (Øien, MS 1992). Associated statistical measures of variability are available for the published abundance estimates. However, since estimating statistical confidence intervals around our preliminary consumption estimates was beyond the scope of our present analysis, we did not compute variances for any of our new or revised estimates, and have not included any estimates of variance in this paper. The species identification of dolphins varied greatly between survey vessels. The largest number of sightings of unidentified dolphins were made in the northern part of the survey area, and are thus likely to be L. albirostris, judging from the known distribution of the two dolphin species occurring regularly in Icelandic waters.
For several species, we then had abundance estimates for both 1987 and 1989 to use in our consumption estimates, while estimates from NASS95 were only available for fin and minke whales at the time of writing of this paper. Thus, for blue and sei whales we used the 1989 data (with one survey block from 1987 added) because of more extensive coverage and/or more appropriate timing of that survey. For fin and minke whales the most recent estimate (1995) was used, with the aerial survey component in 1995 contributing significantly to the latter estimate. The 1987 data were used for humpback whales, dolphins and porpoises due to more appropriate timing of the survey than in 1989. Finally, for sperm, long-finned pilot and northern bottlenose whales the average of 1987 and 1989 were used.

\section{Seasonal patterns of abundance}

Large whales are known to be highly migratory, so their abundance within a given area may vary greatly on a seasonal basis. However, our abundance estimates pertain only to relatively short time during summer - July 1987 or late July-early August 
TABLE 1. Abundance estimates of cetaceans based on the NASS sightings surveys conducted in 1987 and 1989 and 1995, respectively. "Iceland" refers to "Iceland and adjacent waters" (see text). $n$ : number of sightings. $n$ is missing for minke whales as the estimate is mainly based on aerial survey (cue counting).

\begin{tabular}{|c|c|c|c|c|c|}
\hline Species & Area & Year & Abundance & $n$ & Note \\
\hline Blue whale & $\begin{array}{l}\mathrm{N} \text { of } 60^{\circ} \mathrm{N} \\
\text { Iceland }\end{array}$ & $\begin{array}{l}1989 \\
1989\end{array}$ & $\begin{array}{l}878 \\
878\end{array}$ & $\begin{array}{l}32 \\
32\end{array}$ & $\begin{array}{l}1 \\
1\end{array}$ \\
\hline Fin whale & $\begin{array}{l}\mathrm{N} \text { of } 60^{\circ} \mathrm{N} \\
\text { Iceland }\end{array}$ & $\begin{array}{l}1995 \\
1995\end{array}$ & $\begin{array}{r}17427 \\
9867\end{array}$ & $\begin{array}{l}300 \\
171\end{array}$ & $\begin{array}{l}2 \\
2\end{array}$ \\
\hline Sei whale & $\begin{array}{l}\mathrm{N} \text { of } 60^{\circ} \mathrm{N} \\
\text { Iceland }\end{array}$ & $\begin{array}{l}1989 \\
1989\end{array}$ & $\begin{array}{r}1662 \\
375\end{array}$ & $\begin{array}{r}30 \\
7\end{array}$ & $\begin{array}{l}3 \\
3\end{array}$ \\
\hline Minke whale & $\begin{array}{l}\mathrm{N} \text { of } 60^{\circ} \mathrm{N} \\
\text { Iceland }\end{array}$ & $\begin{array}{l}1995 \\
1995\end{array}$ & $\begin{array}{l}65956 \\
62507\end{array}$ & & $\begin{array}{l}4 \\
4\end{array}$ \\
\hline Humpback whale & $\begin{array}{l}\mathrm{N} \text { of } 60^{\circ} \mathrm{N} \\
\text { Iceland }\end{array}$ & $\begin{array}{l}1987 \\
1987\end{array}$ & $\begin{array}{l}1796 \\
1796\end{array}$ & $\begin{array}{l}74 \\
74\end{array}$ & $\begin{array}{l}5 \\
5\end{array}$ \\
\hline Sperm whale & $\begin{array}{l}\mathrm{N} \text { of } 60^{\circ} \mathrm{N} \\
\text { Iceland }\end{array}$ & $\begin{array}{l}1987 \\
1987\end{array}$ & $\begin{array}{ll}2 & 262 \\
1 & 435\end{array}$ & $\begin{array}{l}75 \\
51\end{array}$ & $\begin{array}{l}6 \\
6\end{array}$ \\
\hline $\mathrm{N}$ of $60^{\circ} \mathrm{N}$ & $\begin{array}{l}1989 \\
\text { Iceland }\end{array}$ & $\begin{array}{l}2456 \\
1989\end{array}$ & $\begin{array}{r}54 \\
1163\end{array}$ & $\begin{array}{r}1 \\
27\end{array}$ & 1 \\
\hline Northern Bottlenose whale & $\begin{array}{l}\mathrm{N} \text { of } 60^{\circ} \mathrm{N} \\
\text { Iceland }\end{array}$ & $\begin{array}{l}1987 \\
1987\end{array}$ & $\begin{array}{l}44304 \\
41625\end{array}$ & $\begin{array}{l}85 \\
80\end{array}$ & $\begin{array}{l}1 \\
1\end{array}$ \\
\hline Long-finned pilot whale & $\begin{array}{l}\mathrm{N} \text { of } 60^{\circ} \mathrm{N} \\
\text { Iceland }\end{array}$ & $\begin{array}{l}1987 \\
1987\end{array}$ & $\begin{array}{ll}53 & 211 \\
34 & 824\end{array}$ & $\begin{array}{l}46 \\
35\end{array}$ & $\begin{array}{l}7 \\
7\end{array}$ \\
\hline & $\begin{array}{l}\mathrm{N} \text { of } 60^{\circ} \mathrm{N} \\
\text { Iceland }\end{array}$ & $\begin{array}{l}1989 \\
1989\end{array}$ & $\begin{array}{r}164679 \\
80867\end{array}$ & $\begin{array}{l}45 \\
27\end{array}$ & $\begin{array}{l}7 \\
7\end{array}$ \\
\hline Killer whale & $\begin{array}{l}\mathrm{N} \text { of } 60^{\circ} \mathrm{N} \\
\text { Iceland }\end{array}$ & $\begin{array}{l}1987 \\
1987\end{array}$ & $\begin{array}{ll}5 & 508 \\
5 & 013\end{array}$ & $\begin{array}{l}21 \\
20\end{array}$ & $\begin{array}{l}5 \\
5\end{array}$ \\
\hline White-beaked dolphin & $\begin{array}{l}\mathrm{N} \text { of } 60^{\circ} \mathrm{N} \\
\text { Iceland }\end{array}$ & $\begin{array}{l}1987 \\
1987\end{array}$ & $\begin{array}{r}13420 \\
12341\end{array}$ & $\begin{array}{l}78 \\
72\end{array}$ & $\begin{array}{l}8 \\
8\end{array}$ \\
\hline White-sided dolphin & $\begin{array}{l}\mathrm{N} \text { of } 60^{\circ} \mathrm{N} \\
\text { Iceland }\end{array}$ & $\begin{array}{l}1987 \\
1987\end{array}$ & $\begin{array}{ll}38 & 682 \\
37 & 622\end{array}$ & $\begin{array}{l}93 \\
89\end{array}$ & $\begin{array}{l}8 \\
8\end{array}$ \\
\hline Unidentified dolphin & $\begin{array}{l}\mathrm{N} \text { of } 60^{\circ} \mathrm{N} \\
\text { Iceland }\end{array}$ & $\begin{array}{l}1987 \\
1987\end{array}$ & $\begin{array}{l}36701 \\
26672\end{array}$ & $\begin{array}{r}118 \\
86\end{array}$ & $\begin{array}{l}8 \\
8\end{array}$ \\
\hline Harbour porpoise & $\begin{array}{l}\mathrm{N} \text { of } 60^{\circ} \mathrm{N} \\
\text { Iceland }\end{array}$ & $\begin{array}{l}1987 \\
1987\end{array}$ & $\begin{array}{ll}28 & 514 \\
26 & 843\end{array}$ & $\begin{array}{l}47 \\
45\end{array}$ & $\begin{array}{l}8 \\
8\end{array}$ \\
\hline
\end{tabular}

1 Estimate based on data from Sigurjónsson et al., 1991, same methods as in Gunnlaugsson and Sigurjónsson (1990).

2 Borchers and Burt, MS 1997; NAMMCO, 1997.

3 Cattanach et al., 1993.

4 Borchers et al., MS 1997; NAMMCO, 1997.

5 Estimate from Gunnlaugsson and Sigurjónsson, 1990.

6 Estimate from Gunnlaugsson and Sigurjónsson, 1990, but corrected for diving animals; group size and distribution of sightings based on Sigurjónsson et al., 1989.

7 Buckland et al., 1993.

8 Based on data in Sigurjónsson et al., 1989; assumptions on track-width (see text).

1989. We therefore used sighting records kept onboard operating whaling vessels during 1979-85 to estimate the seasonal pattern of relative abundance. The sighting records included date, location, species identification, estimated group size, and other detailed information for each sighting event (see detailed description of the data in Sigurjónsson and Gunnlaugsson, 1990). The records were primarily from June through September, with sporadic observations in May and October. The number of 
individuals sighted of each species was tallied within half-month intervals. These totals were then corrected for varying levels of search effort using the actual days of operation for each vessel and the mean time from sunrise to sunset (at Reykjavík) within each interval. We termed the resulting index (see Fig. 2) sightings per effective operation time (SEOP).

For most of the large whales, historical catch records (see e.g. Risting, 1922) and recent incidental sightings around Iceland (MRI, unpubl. data) indicate significant though low, abundance off Iceland during off-season months, but the level is not known. Relative abundance outside the months of June through September was estimated as follows. For blue whales (Fig. 2a) and sperm whales (Fig. $2 \mathrm{e})$, the off season value was arbitrarily set at $10 \%$ of peak summer abundance and the values for the periods before and after the study season were adjusted according to the shape of the seasonal curve. This was done by linear regression to determine the slope of the curve during spring. For fin whales (Fig. 2b) the September level (9.3\% of peak abundance in the latter half of June) was used as the off season abundance index, and abundance in the first half of May was assumed to be similar to that in late September. For humpbacks (Fig. 2d) the lateMay SEOP value was included and $10 \%$ used as off season level. Sei whales (Fig. 2c) were assumed to be absent during the winter months as no records of sightings of this species in Icelandic waters during winter are available. The SEOP for sei whales was equal to nil until late June, but an assumed mirror-reflected level was chosen in the autumn.

The seasonal sightings curve for minke whales west and southwest of Iceland only partly reflects the real situation for Iceland since catch records show that minke whales were caught as early as March and as late as November (Sigurjónsson, 1982). Therefore, an uncorrected catch series for one of the most active minke whalers in operation in the 1970s was used to indicate relative seasonal abundance (Fig. 2f). This vessel operated north of Iceland but although its catch distribution may, to some extent, be out of phase with the peak abundance of minke whales in other areas it is likely to reflect the length of the season. Only the years 1978 (the first year of available minke whale catch records) to 1980 were included, since the period after that is seriously biased due to restrictions set by catch limits in later years. The off season level was arbitrarily assumed to be $10 \%$ of peak abundance.
The observations onboard the whaling vessels of the medium-sized species (killer, pilot and northern bottlenose whales) are probably less reliable than for large whales due to lack of economic interest in these species (see Sigurjónsson and Gunnlaugsson, 1990) and almost no sightings of the smaller dolphins and porpoises were recorded. Therefore, the sightings data for these species were not considered suitable for the present purpose and we simply assumed, based on sporadic evidence (MRI, unpubl. data) that they occur year-round in our study area. One exception is the northern bottlenose whale, where seasonal catches (Benjaminsen, 1972; Benjaminsen and Christensen, 1979) show a marked peak in June, the bulk of the catches being taken in the area east and northeast of Iceland towards the Jan Mayen Island. This same area had by far the greatest abundance in the 1987 survey (approx. 75\%). Since Norwegian regulations for catches of small whales, including this species (Jonsgård, 1977), set limitations on catch operations in July, only the catch curve through June was used here (see Fig. 2g, based on Benjaminsen, 1972) to estimate the seasonality off Iceland. For the period July-September we assumed a steady decline from the late June level to the assumed winter abundance of $10 \%$, starting in late September.

The absolute abundance estimates were then linked to the seasonal relative abundance curves. The absolute abundance value from the NASS data was assigned to the appropriate half-month-interval, and then abundance estimates for all other intervals were calculated in proportion to the relative abundance indices. The one exception was the northern bottlenose whale, where the July relative abundance index was assumed because of the bias in the catch data. The absolute abundance estimate for that species was assigned to the late June interval.

\section{Prey}

As many cetacean species appear to be opportunistic in food selection, varying prey both in time and space, all available information from Icelandic and adjacent waters was used in the assessment of food composition. This is, however, rather limited for most species. In cases where no local material was available, data from other localities throughout the North Atlantic was used. Even for the species most extensively studied (e.g. the recently harvested fin, sei and minke whales), the data are far from complete with respect to time and space. Therefore, due to lack of more detailed information on prey species, we classified the prey into three 

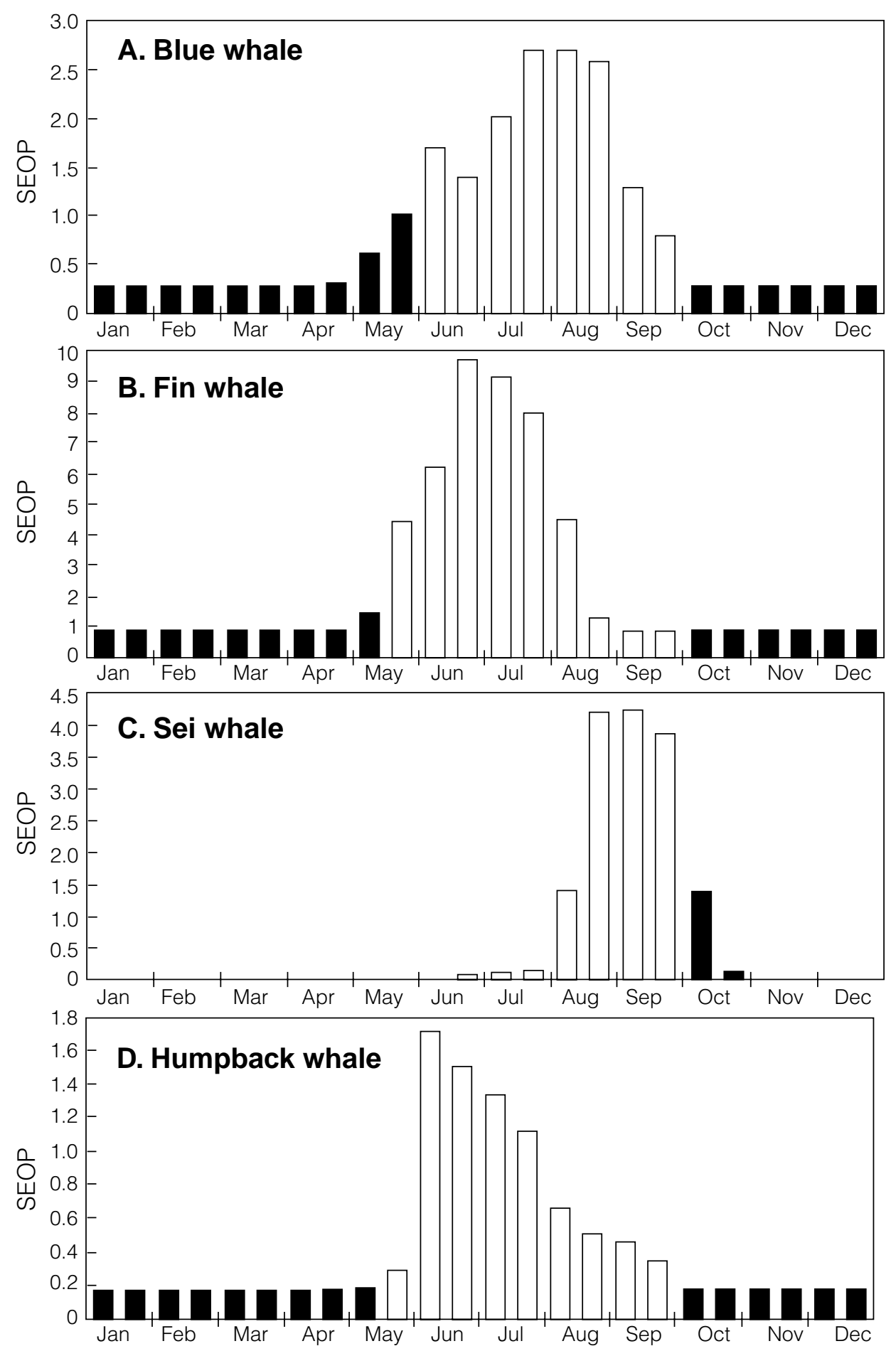

Fig. 2. Relative seasonal abundance of baleen whales (a-d, f), sperm whales (e) and northern bottlenose whales $(\mathrm{g})$ in Icelandic waters. a-e are based on sightings data from whaling vessels while $\mathrm{f}-\mathrm{g}$ are based on catch data. White bars are calculated directly from the data, black bars indicate assumed winter distribution. The unit SEOP (Sightings per effective operation time) does not necessarily indicate the relative abundance of the different species. 

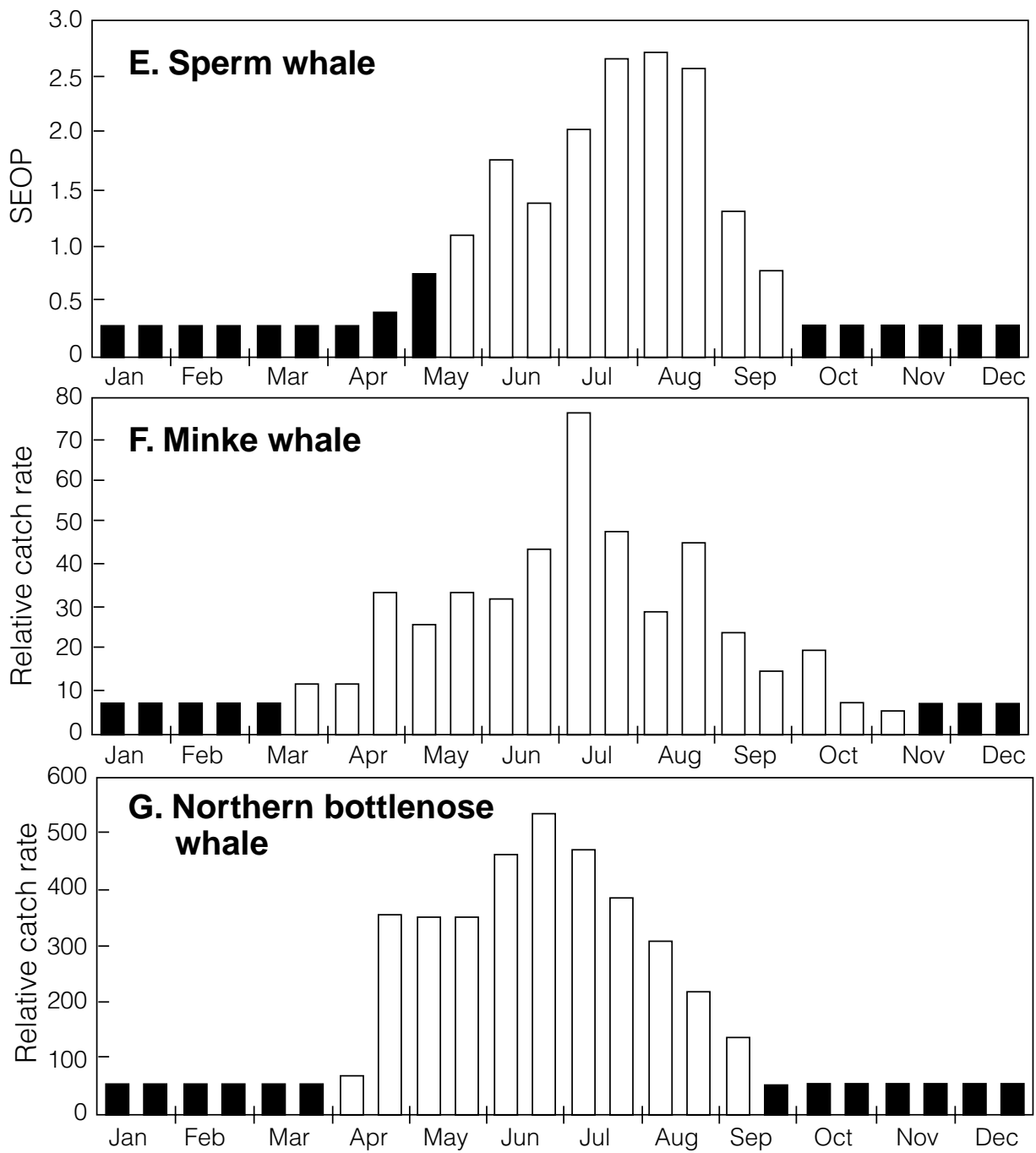

Fig. 2. (Continued). Relative seasonal abundance of baleen whales (a-d, f), sperm whales (e) and northern bottlenose whales (g) in Icelandic waters. a-e are based on sightings data from whaling vessels while $f-g$ are based on catch data. White bars are calculated directly from the data, black bars indicate assumed winter distribution. The unit SEOP (Sightings per effective operation time) does not necessarily indicate the relative abundance of the different species.

groups, crustaceans, cephalopods and finfish (see Table 2).

\section{Estimation of consumption}

As the abundance estimates for the whale stocks off Iceland were not stratified by age or length classes, calculations of consumption rates were based on mean weights. For fin and sei whales, weight/length equations based on Icelandic catch data were used (Víkingsson et al., 1988), but for other large whales the equations of Lockyer (1976) were applied to the Icelandic length distributions. Mean weights of harbour porpoises and whitebeaked dolphins were derived from incidental catches off Iceland (MRI, unpubl. data) but information on other species of small and medium sized cetaceans was obtained from the literature (see Table 3 ). The mean weight of northern bottlenose whales was calculated from the weight of blubber and meat (Benjaminsen and Christensen, 1979), assuming that these constituted $69 \%$ of the total body weight as in killer whales (Christensen, 1982). 
TABLE 2. Assumed food composition (\% weight) of cetaceans in Icelandic and adjacent waters.

\begin{tabular}{|c|c|c|c|c|}
\hline Species & Fish & Cephalopoda & Crustacea & Source \\
\hline Blue whale & & & 100 & Hjort and Ruud, 1929; Tomilin, 1967 \\
\hline Fin whale & 3 & & 97 & MRI* \\
\hline Sei whale & 2 & & 98 & MRI* \\
\hline Minke whale & 59 & & 41 & Sigurjónsson and Galan, 1991 \\
\hline Humpback whale & 60 & & 40 & Mitchell, 1973 \\
\hline Sperm whale & 76 & 24 & & Martin and Clarke, 1986 \\
\hline Northern Bottlenose whale & 5 & 95 & & Benjaminsen and Christensen, 1979 \\
\hline Pilot whale & 20 & 80 & & $\begin{array}{l}\text { Desportes and Mouritsen, 1993; } \\
\text { Sigurjónsson et al., } 1993\end{array}$ \\
\hline Killer whale & 100 & & & MRI* \\
\hline White-sided dolphin & 95 & 5 & & $\begin{array}{l}\text { Evans, 1980; Tomilin, 1967; Katona et al., 1978, } \\
\text { Sergeant et al., } 1980\end{array}$ \\
\hline White-beaked dolphin & 95 & 5 & & MRI*; Evans, 1980; Tomilin, 1967 \\
\hline Harbour porpoise & 95 & 5 & & $\begin{array}{l}\text { MRI*; Evans, 1980; Tomilin, } 1967 \\
\text { Víkingsson and Sigurjónsson, MS } 1996\end{array}$ \\
\hline
\end{tabular}

* Unpublished information from the Marine Research Institute, Reykjavík, Iceland.

TABLE 3. Estimated mean weight ( $\mathrm{kg})$ of cetaceans used in this study.

\begin{tabular}{lrl}
\hline \hline Species & Weight & \multicolumn{1}{c}{ Source } \\
\hline Blue whale & 69235 & * Lockyer, 1976 \\
Fin whale & 42279 & * Víkingsson et al., 1988 \\
Sei whale & 19919 & *Víkingsson et al., 1988 \\
Minke whale & 5251 & * Lockyer, 1976 \\
Humpback whale & 31782 & * Lockyer, 1976 \\
Sperm whale & 34322 & * Lockyer, 1976 \\
Northern Bottlenose whale & 5418 & Benjaminsen and Christensen, 1979; \\
& & Benjaminsen, 1972; Christensen, 1982 \\
Pilot whale & 789 & Bloch and Lockyer, MS 1989 \\
Killer whale & 2350 & Christensen, 1982 \\
White-sided dolphin & 190 & Watson, 1981 \\
White-beaked dolphin & 225 & MRI, unpubl. data \\
Harbour porpoise & 39 & MRI, unpubl. data \\
\hline
\end{tabular}

* Calculated from catch data by weight/length formula.

The average weight values were adjusted for sexual size difference and uneven sex ratio as observed in the catch of this species off Iceland (Benjaminsen, 1972). 
Ingestion rates were calculated by two methods:

a) calculations based on actual feeding rates of cetaceans in captivity (Sergeant, 1969). The formula modified by Innes et al. (1986) and Armstrong and Siegfried (1991) was used:

$$
I=0.42 M^{0.67}
$$

where $I$ is the ingestion rate $(\mathrm{kg} / \mathrm{day})$ and $M$ is body weight in $\mathrm{kg}$. As the underlying data were based on fish consumption, the value $1.3 \mathrm{kcal} / \mathrm{g}$ was used for conversion into energy units (Steimle and Terranova, 1985).

b) Calculations of energy requirements based on assumptions regarding the relationship between physiological parameters and body weight. Using Lockyer's (1981b) "near-basal metabolic rate" and assuming an assimilation rate of $80 \%$ and an activity coefficient of 1.5 (Overholtz et al., 1991; Hinga, $1979)$ the daily ration is given by:

$$
D=206.25 M^{0.783}
$$

where $D$ is the daily active ration (kcal/day) and $M$ is the body weight in $\mathrm{kg}$.

For the highly migratory baleen whales the large seasonal variation in feeding intensity has to be taken into account. Although very little information exists on the winter distribution and biology of most North Atlantic rorquals, energetic studies on the summer feeding grounds (Lockyer, 1987a, 1987b; Víkingsson, 1990, 1995), as well as feeding studies from the southern hemisphere (summarized in Lockyer, 1981a), indicate that these species obtain most of their yearly energy needs during the approximately 4 month summer period of intense feeding at high latitudes. According to Lockyer (1981a) around 83\% of the annual energy intake in southern hemisphere balaenopterids is ingested during the summer season, corresponding to approximately ten times higher feeding rates during the summer than in winter. Based on this assumption, calculations on mean daily feeding rates during the 120 days summer period (mid-May to mid-September) and during winter (mid-Septembermid May) were made for the baleen whales by the following equations:

$$
\begin{gathered}
S=2.53 D \\
W=0.235 D
\end{gathered}
$$

where $S$ and $W$ are the summer and winter ingestion rates, respectively, and $D$ is the mean ingestion rate on an annual basis. In the absence of data on seasonal fattening in odontocetes no attempt was made to allow for possible increased summer feeding rates of these species, although judging from the migratory behaviour of some species this does not seem unlikely.

The conversion factors $0.93 \mathrm{kcal} / \mathrm{g}$ for crustaceans (Lockyer, 1987a) and $1.3 \mathrm{kcal} / \mathrm{g}$ for fish and cephalopods (Steimle and Terranova, 1985) were used for calculations of ingested biomass in the absence of data on seasonal variation in energy content of prey species. To calculate the annual consumption of each species we multiplied abundance by daily ration and the number of days for each halfmonth, and then summed all the half-month periods of the year.

\section{Results}

The abundance estimates used in the calculations are given in Table 1, separately for the two areas "Iceland and adjacent waters" and "north of $60^{\circ} \mathrm{N"}$.

Data on diet of cetaceans in Icelandic waters were available for fin, sei, minke, sperm and longfinned pilot whales, white-beaked dolphins and harbour porpoises, while extrapolations from other areas within the North Atlantic had to be made for other species (Table 2). Most of the Icelandic data are unpublished.

For the fin whale we assumed that $3 \%$ of the food was composed of fish and $97 \%$ of planktonic euphausiids. This was based on observations of fin whales landed, during June-September 1967-89, at the Hvalfjördur whaling station, Southwest Iceland. Of 1609 whales examined, 96\% had krill only in their stomachs, $0.7 \%$ capelin (Mallotus villosus) only, $0.1 \%$ sandeel (Ammodytidae) only, $0.8 \%$ some fish remains and $2.5 \%$ a mixture of krill and fish remains. Of the fish, it was estimated that capelin comprised some $2.4 \%$ and other species of fish (mainly juveniles) like blue whiting (Micromesistius poutassou) comprised less than $1 \%$. Of 159 stomach samples examined during the 197989 seasons and containing krill, $99.4 \%$ had Meganyctiphanes norvegica but only one Thysanoessa longicaudata.

Of 247 sei whales caught during 1967-88 and analysed for stomach contents, 243 (98\%) had eaten planktonic crustaceans, two had eaten sandeels and one each lumpfish and capelin, respectively. 
A limited sample of 58 minke whales was examined during 1977-90 (Sigurjónsson and Galan, 1991). Based on these observations 59\% of the food is taken to be fish and $41 \%$ krill. No stomach samples are available from humpback whales in Icelandic waters, but Canadian studies indicate a ratio of 60:40 fish:krill diet (Mitchell, 1973), which may be in accordance with the very often reported occurrence of humpback whales at the capelin grounds around the coast of Iceland and behavioural observations (MRI, unpubl. data).

Visual observations of killer whales in Icelandic waters indicate that herring is their main food in Icelandic waters (Sigurjónsson et al., 1988; MRI, unpubl. information). Although killer whales have occasionally been observed chasing seals and seabirds off Iceland (Karl Gunnarsson, MRI, Iceland, pers. comm.) a $100 \%$ fish diet was assumed for the present analysis (Table 2). While limited examinations on stomach contents of whitebeaked dolphins by-caught in Icelandic waters indicated almost total dominance of fish in the diet, we here assume that $5 \%$ of the food of both dolphin species is cephalopods in accordance with studies elsewhere in the North Atlantic (Tomilin, 1967; Katona et al., 1978; Evans, 1980; Sergeant et al., 1980).

The estimated mean weights of cetaceans in Icelandic and adjacent waters ranged from $39 \mathrm{~kg}$ for the harbour porpoise to nearly 70 tons for the blue whale (Table 3).

The calculated daily food consumption by the two methods, A and B, is given in Table 4. The results of the estimation of annual consumption of finfish, cephalopods and crustacea (mainly krill) by species of whales are given in Tables 5 and 6. Figure 3 shows the general pattern of proportions of food type consumed by the different whale species according to this study for method $\mathrm{A}$ in the larger area, north of $60^{\circ} \mathrm{N}$. The total food consumption of all cetacean species is around 8.8 million tons and 6.3 million tons north of $60^{\circ} \mathrm{N}$ and in Icelandic and adjacent waters, respectively, according to method A. The corresponding figures for method B are slightly higher or 9.2 and 6.5 million tons, respectively. The four largest consumers in the area north of $60^{\circ} \mathrm{N}$ placed in descending order were: fin, minke, pilot and northern bottlenose whales. These four species accounted for around $80 \%$ of the total cetacean consumption in the larger area. Fin and minke whales alone consumed 4.8 million tons or
$55 \%$ of the total. Within the smaller area, 'Iceland and adjacent waters', minke whales were the greatest consumers, followed by fin whales and then pilot and northern bottlenose whales. Here, minke whales alone were responsible for $33 \%$ of the total cetacean consumption ( 2.1 million tons), while the four species together consumed similar proportion of the total as in the larger area (Table 5).

Crustaceans were consumed by all of the baleen whales and comprised around $51 \%$ of the total consumption in the larger area, but $46.5 \%$ in the smaller area according to method A. Method B gives somewhat higher proportion of crustaceans consumed; $58 \%$ and $52 \%$ of the larger and smaller areas, respectively.

According to these calculations, finfish comprised 24-27\% (depending on methods A-B) of the cetacean food within the larger area. The proportion of fish was somewhat higher, $29-32 \%$ in the more nearshore waters of the smaller area, where total consumption of fish was around 2 million tons. Although cephalopods were taken by several odontocete species, the majority were consumed by pilot and northern bottlenose whales, accounting for between 36 and $60 \%$ each of the total cephalopods consumed, depending on which method and area was considered. Together these two species consumed $97 \%$ of the total consumption of cephalopods.

On the other hand, finfish were consumed by most species of whales and amounted to 2.2-2.4 million tons for the area north of $60^{\circ} \mathrm{N}$ and 1.9-2.0 million tons for Icelandic and adjacent waters. The estimated amount determined by method A for the Icelandic and adjacent seas is shown in Fig. 4. According to the present calculations (method A) minke whales were, by far, the most important fish eaters around Iceland, consuming around 1 million tons of fish in Icelandic and adjacent waters, corresponding to $52 \%$ of the total fish consumption by cetaceans in the area. White-sided dolphins, longfinned pilot whales, killer whales and humpback whales each consumed 6-9\% of the total cetacean fish consumption in the small area (Tables 5-6). Unidentified dolphins and white-beaked dolphins together consumed more fish than white-sided dolphins, so taken together dolphins were the second greatest fish consumers in the area, accounting for $19 \%$ and $14 \%$ of the total fish consumtion in the smaller area according to methods A and B, respectively. 
TABLE 4. Estimated energy consumption (thousands of Kcal/day) by whale species and season based on two different methods A and B (see text).

\begin{tabular}{|c|c|c|c|c|c|c|}
\hline \multirow[b]{2}{*}{ Species } & \multicolumn{2}{|c|}{ Mean } & \multicolumn{2}{|c|}{ Summer } & \multicolumn{2}{|c|}{ Winter } \\
\hline & A & $\mathrm{B}$ & A & $\mathrm{B}$ & A & $\mathrm{B}$ \\
\hline Blue whale & 955.4 & 1271.5 & 2421.3 & 3211.8 & 222.5 & 301.4 \\
\hline Fin whale & 686.6 & 864.2 & 1734.4 & 2183.0 & 162.7 & 204.8 \\
\hline Sei whale & 414.7 & 479.4 & 1047.5 & 1211.0 & 98.3 & 113.6 \\
\hline Minke whale & 169.7 & 168.8 & 428.7 & 426.4 & 40.2 & 40.0 \\
\hline Humpback whale & 567.1 & 691.1 & 1432.1 & 1745.7 & 134.6 & 163.8 \\
\hline Sperm whale & 597.1 & 734.0 & & & & \\
\hline Northern Bottlenose whale & 173.3 & 173.0 & & & & \\
\hline Pilot whale & 47.7 & 38.3 & & & & \\
\hline Killer whale & 99.0 & 89.9 & & & & \\
\hline Unidentified dolphin & 19.5 & 13.5 & & & & \\
\hline White-sided dolphin & 18.4 & 12.5 & & & & \\
\hline White-beaked dolphin & 20.6 & 14.3 & & & & \\
\hline Harbour porpoise & 6.4 & 3.6 & & & & \\
\hline
\end{tabular}

TABLE 5. Consumption by species (tons) north of $60^{\circ} \mathrm{N}$ and around Iceland by method A (see text).

\begin{tabular}{|c|c|c|c|c|c|c|c|c|}
\hline \multirow[b]{2}{*}{ Species } & \multicolumn{4}{|c|}{ North of $60^{\circ} \mathrm{N}$} & \multicolumn{4}{|c|}{ Iceland } \\
\hline & Fish $\mathrm{Ce}$ & Cephalopoda & Crustacea & Total & Fish Cep & phalopoda & Crustacea & Total \\
\hline Blue whale & & & 206364 & 206364 & & & 206364 & 206364 \\
\hline Fin whale & 56598 & & 2558085 & 2614683 & 32045 & & 1448363 & 1480408 \\
\hline Sei whale & 7895 & & 540797 & 548692 & 1781 & & 122021 & 123802 \\
\hline Minke whale & 1113847 & & 1081977 & 2195824 & 1055602 & & 1025398 & 2081000 \\
\hline Humpback whale & 118889 & & 110792 & 229681 & 118889 & & 110792 & 229681 \\
\hline Sperm whale & 105519 & 33322 & & 138841 & 58104 & 18349 & & 76453 \\
\hline $\begin{array}{l}\text { Northern Bottlenose } \\
\text { whale }\end{array}$ & 36523 & 693941 & & 730464 & 34315 & 651980 & & 686295 \\
\hline Pilot whale & 291813 & $3 \quad 1167253$ & & 1459067 & 154943 & 619771 & & 774714 \\
\hline Killer whale & 153101 & & & 153101 & 139342 & & & 139342 \\
\hline $\begin{array}{l}\text { White-beaked } \\
\text { dolphin }\end{array}$ & 73738 & 3881 & & 77619 & 67810 & 3569 & & 71378 \\
\hline $\begin{array}{l}\text { White-sided } \\
\text { dolphin }\end{array}$ & 189845 & 9992 & & 199837 & 184643 & 9718 & & 194361 \\
\hline $\begin{array}{l}\text { Unidentified } \\
\text { dolphins }\end{array}$ & 190891 & 10047 & & 200938 & 138728 & 7301 & & 146029 \\
\hline Harbour porpoise & 48676 & 2562 & & 51237 & 45823 & 2412 & & 48235 \\
\hline Total & 2387336 & $6 \quad 1920998$ & 4498015 & 8806349 & 2032024 & 1313100 & 2912938 & 6258062 \\
\hline
\end{tabular}

\section{Discussion}

Although the two methods for calculating the average daily feeding rates give similar results for the total consumption of all populations (Tables 56 ), they differ considerably in the extremes of the size range of species (Table 4) and thus with regard to the proportional contribution of the different 
TABLE 6. Consumption by species (tons) north of $60^{\circ} \mathrm{N}$ and around Iceland by method B (see text).

\begin{tabular}{|c|c|c|c|c|c|c|c|c|}
\hline \multirow[b]{2}{*}{ Species } & \multicolumn{3}{|c|}{ North of $60^{\circ} \mathrm{N}$} & \multirow[b]{2}{*}{ Total } & \multicolumn{3}{|c|}{ Iceland } & \multirow[b]{2}{*}{ Total } \\
\hline & Fish $\mathrm{Ce}$ & ephalopoda & Crustacea & & Fish $\mathrm{Ce}$ & Cephalopoda & Crustacea & \\
\hline Blue whale & & & 274791 & 274791 & & & 274791 & 274791 \\
\hline Fin whale & 71238 & & 3219738 & 3290976 & 40334 & & 1822985 & 1863319 \\
\hline Sei whale & 9128 & & 625208 & 634336 & 2060 & & 141067 & 143127 \\
\hline Minke whale & 1107894 & & 1076193 & 2184087 & 1049959 & & 1019917 & 2069876 \\
\hline Humpback whale & 144914 & & 135046 & 279960 & 144914 & & 135046 & 279960 \\
\hline Sperm whale & 129712 & 40962 & & 170674 & 71427 & 22556 & & 93983 \\
\hline \multicolumn{8}{|l|}{ Northern Bottlefish } & 685106 \\
\hline Pilot whale & 234307 & 937229 & & 1171536 & 124409 & 497636 & & 622045 \\
\hline Killer whale & 139028 & & & 139028 & 126534 & & & 126534 \\
\hline \multicolumn{9}{|l|}{ White-beaked } \\
\hline dolphin & 51187 & 2694 & & 53881 & 47072 & 2477 & & 49549 \\
\hline White-sided dolphin & 128971 & 6788 & & 135759 & 125437 & 6602 & & 132039 \\
\hline Unidentified dolphins & s 132155 & 6956 & & 139111 & 96042 & 5055 & & 101097 \\
\hline Harbour porpoise & 27380 & 1441 & & 28821 & 25775 & 1357 & & 27132 \\
\hline Total & 2212375 & 1688809 & 5330976 & 9232160 & 1888218 & $8 \quad 1186534$ & 3393806 & 6468558 \\
\hline
\end{tabular}

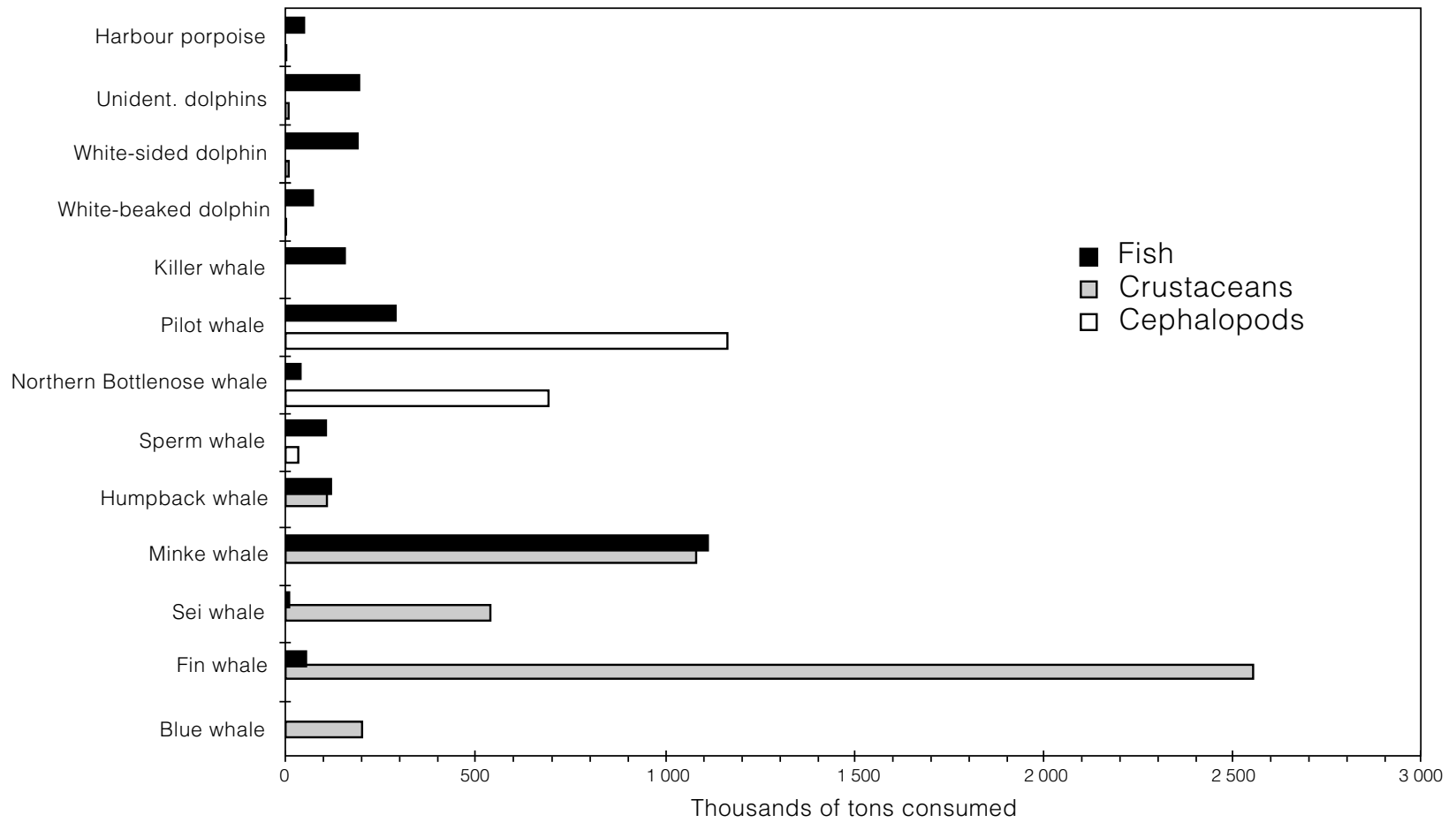

Fig. 3. Estimated consumption (thousands of tons) of crustaceans, cephalopods and finfish by cetaceans in the larger survey area north of $60^{\circ} \mathrm{N}$.

species to the total consumption. As the underlying data for method $\mathrm{A}$ are based on measurements of small and medium sized cetaceans in captivity (Sergeant, 1969), we consider that method more reliable for those species. However, the summer ingestion rates obtained by method $\mathrm{A}$ also appear to be in better agreement with studies on seasonal fattening rates and quantities of stomach content in large whales (Kawamura, 1974; Lockyer, 1981a, 1987a, 1987b; Víkingsson, 1995, 1997). 


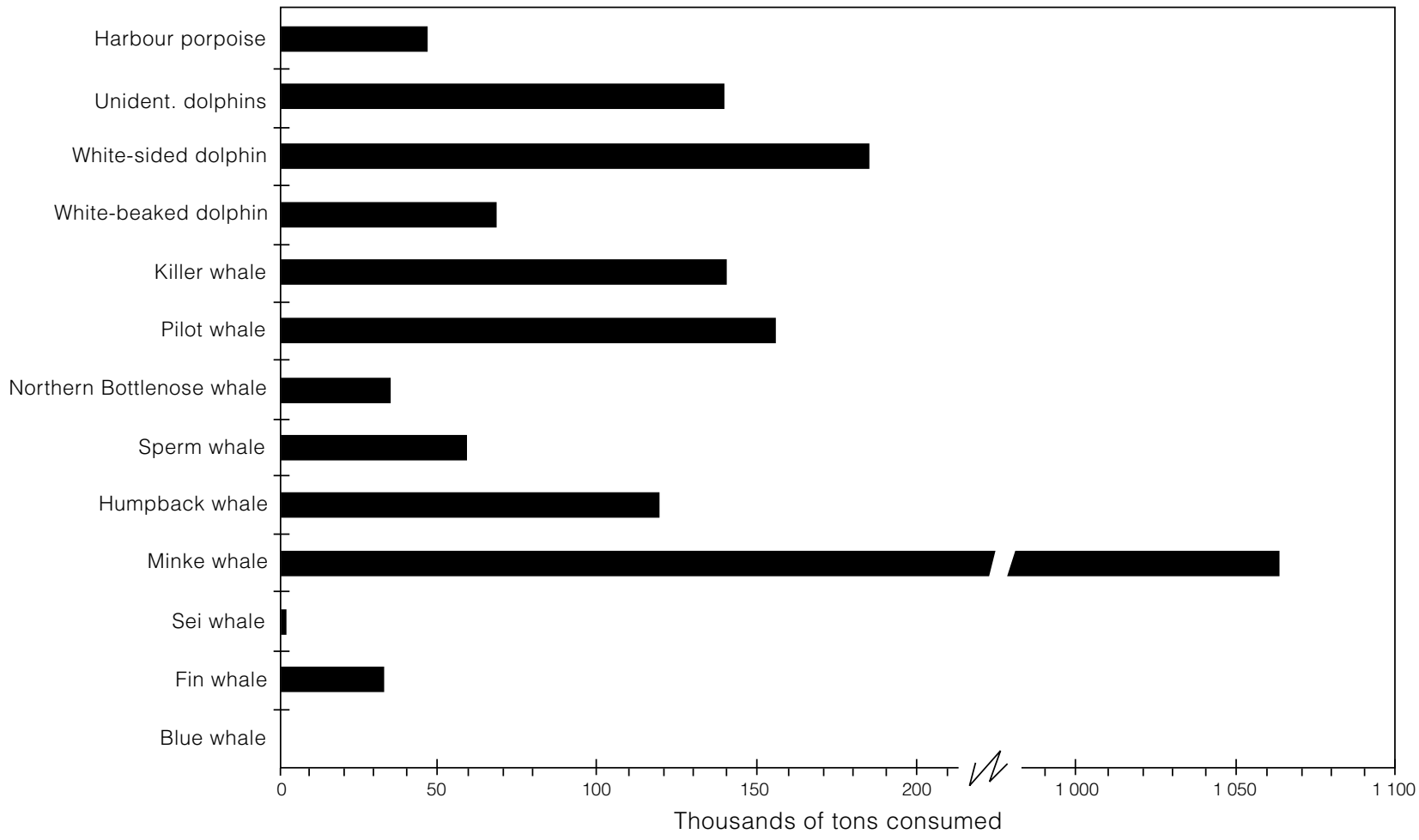

Fig. 4. Estimated consumption (thousands of tons) of finfish by cetaceans in the smaller survey area "Iceland and adjacent waters".

Mean weights calculated from the length distribution of the catch of fin and sei whales are probably somewhat overestimated because of the IWC (International Whaling Commission) regulations on minimum size limits and probable size selection by whalers. This may, however, be balanced by increased metabolic rate (Kleiber, 1975; Lavigne et al., 1986) of growing individuals and possible segregation (IWC, 1986) with older animals migrating farther polewards resulting in positively skewed age distribution around Iceland.

The calculations by Markussen et al. (1992) on consumption of minke whales off Norway gave approximately $20 \%$ lower mean consumption rates for individual minke whales than the present results. However, the present results on total consumption of fin, sei and blue whales are around $20 \%$ lower than simple calculations based on the assumptions that the whole populations (the peaks of the migration curves) stay in the area for 120 days, but are absent the rest of the year and either i) feed at the summer rates $(35 \mathrm{~g} / \mathrm{kg}$ body weight) given by Lockyer (1981a) or ii) one assumes two times Kleiber's (1975) basal metabolic rates as often done for mammals in general (Innes et al., 1987).
It has become evident from this study how sensitive the results are to the various input parameters and assumptions required to reach a conclusion. Particularly critical are the estimates of abundance for all species and it needs be emphasized that some of these require further study. This applies specifically to all the odontocete species, although the estimates for killer and pilot whales are probably the best that can be obtained based on the available data. The great variations in group sizes of many of the odontocetes is of concern since they result in wide confidence intervals of the abundance estimates (e.g. in pilot whales), which we have not considered here. The corrections applied here for animals missed on the track-line when the surveys were conducted (i.e. for northern bottlenose whale, sperm whale and harbour porpoise) also need further elaboration. And finally, it needs to be kept in mind which are the target species for the various surveys, when using sightings survey data. The NASS surveys were designed primarily for abundance estimation of large baleen whales and the provisional estimates for the smaller species are therefore likely to be biased downward. This may apply especially to the harbour porpoise, where specially designed surveys (Borchers et al., 1995; 
Hammond et al., 1995; Palka, 1995; Polacheck, 1995) are needed for proper abundance estimation.

Another factor of importance is the seasonal variation in abundance. Although we believe our approach to some extent solves this problem, more information is needed on migratory behaviour and geographical variation within the study area. The linking between the absolute abundance estimates and the relative indices of seasonal abundance is a potential source of bias. If the peak of the relative index is much out of phase with the reference period for the survey estimate, this will seriously affect the estimate of the total biomass, but does not, however, necessarily cause a bias in that estimate. The peak period for blue whales coincided with the survey period, while this was somewhat out of phase, although not seriously, for fin, minke and humpback whales. It was more severely out of phase for sperm whales and for sei whales; the two were badly out of phase. Although the survey estimate was obtained mainly in the latter half of July and first half of August 1989, i.e. rather late in the season, the seasonal sei whale sightings data suggest that abundance was less than $20 \%$ of the peak in late September, resulting in considerable scalingup of the half-monthly estimates in the latter part of the season. As mentioned above, the relative index for northern bottlenose whale was seriously biased in July.

Whether all age and sex groups behave the same way, could also be of importance in further calculations. Winter abundance is poorly known, but would be useful to look into further, both with respect to feeding activities and what portion of the stock overwinters. Recent studies on fin whales off Iceland have indicated a somewhat longer feeding season than assumed here, especially for younger animals (Víkingsson, 1995). This could further be addressed with respect to humpback whales that often occur on the winter capelin grounds in the deep waters off Iceland. In general, the continuation of ongoing studies into the energetics and feeding rates of different whale species is needed.

There is a strong need for a more extensive data base of actual observations of food composition by each species, including studies of temporal and spatial variation. In the present study the bias is not serious for species like the blue whale, which appears to feed almost exclusively on planktonic crustacea in all oceans (Yochem and Leatherwood,
1985), or the long-finned pilot whale, where extensive studies in the Faroe Islands (Desportes and Mouritsen, 1993) have given a reliable basis for calculations. But for other species like minke and fin whales, which appear to be highly opportunistic in food selection in the northern hemisphere (see e.g. Mitchell, 1975; Jonsgård, 1966; Horwood, 1990; Sigurjónsson, 1995; Haug et al., 1996) and eat both different fish species and euphausiids (off Iceland mainly Meganyctiphanes norvegica) the situation is more difficult. Our observations for fin and sei whales show that these species feed almost exclusively on crustacea during the summer season west and southwest of Iceland, while at least off the Canadian coast, fin whales are well known fish eaters. The large fish consumption by minke whales in Icelandic and adjacent waters and the coastal distribution of the species (NAMMCO, 1997), overlapping to a large extent with the most important fishing grounds off Iceland, may lead to conflicts with fisheries and calls for further studies into the feeding ecology of minke whales in the area.

The energy content of the food, which may vary seasonally and between years, is obviously also very critical in all calculations based on energy requirements. The trophic levels, at which the animals seek their energy resource, is still another important factor with respect to the potential impact on the ecosystem.

The present analysis of consumption by whales, dolphins and porpoises in the area between Greenland, Iceland, Jan Mayen and the Faroe Islands is thus just one step towards a better understanding of the role of cetaceans in the marine ecosystem in these waters. The results show, however, that the total biomass consumed is substantial, or more than three times the total landings of the Icelandic fishing fleet. The implications of this requires further study. Some initial exploration of the potential dynamic relationships between some of the fish resources in this area and three baleen whale species feeding partly on fish, is given in Stefánsson et al. (1997).

\section{Acknowledgements}

Sincere thanks are extended to our colleagues at the MRI. Thorvaldur Gunnlaugsson is thanked for useful suggestions and advice regarding the abundance estimates, Droplaug Ólafsdóttir for useful suggestions and help with the figures and Inga 
F. Egilsdóttir for assistance in the preparation of the manuscript. Two anonymous reviewers are thanked for very useful suggestions.

\section{References}

ARMSTRONG, A. J. and W. R. SIEGFRIED. 1991. Consumption of Antarctic krill by minke whales. Antarctic Science, 3 (1): 13-18.

BENJAMINSEN, T. 1972. On the biology of the bottlenose whale, Hyperoodon ampullatus (Forster). Norweg. J. Zool., 20: 233-241.

BENJAMINSEN, T., and I. CHRISTENSEN. 1979. The natural history of the bottlenose whale, Hyperoodon ampullatus (Forster). In: Behavior of Marine Animals. H.E. Winn and B.L. Olla (eds.). Plenum Press, New York: 143-164.

BJØRGE, A., and N. ØIEN. 1995. Distribution and abundance of harbour porpoise, Phocoena phocoena, in Norwegian waters. Rep. Int. Whal. Comm., (special issue) 16: 89-98.

BLOCH, D., and C. LOCKYER. MS 1989. Age related parameters of the pilot whale off the Faroe Islands IWC SC Doc. SC/41/SM15.

BORCHERS, D. L., and M. L. BURT. MS 1997. Sei and fin whale abundance in the North Atlantic, estimated from NASS-95 shipboard survey data. NAMMCO SC Doc., No. SC/5/AE1, 16 p.

BORCHERS, D. L., S. T. BUCKLAND, E. D. CLARKE, and S. L. CUMBERWORTH. 1995. Estimation of cetacean abundance from the SCANS shipboard survey in summer 1994. Rep. Int. Whal. Comm., 46: 676-677 (abstract).

BORCHERS, D. L., M. McCRACKEN, TH. GUNNLAUGSSON and M. L. BURT. MS 1997. Estimates of minke whale abundance from the 1987 and 1995 NASS aerial surveys. NAMMCO SC Doc., No. SC/ 5/AE2, $13 \mathrm{p}$.

BRODIE, P. F. 1975. Cetacean energetics, an overview of intraspecific size variation. Ecology, 56: 152 161.

BUCKLAND, S. T., D. BLOCH, K. L. CATTANACH, TH. GUNNLAUGSSON, K. HOYDAL, S. LENS, and J. SIGURJÓNSSON 1993. Distribution and abundance of long-finned pilot whales in the North Atlantic, estimated from NASS-87 and Nass-89 data. Rep. Int. Whal. Comm., (special issue) 14: 33-49.

CATTANACH, K. L., J. SIGURJÓNSSON, S. T. BUCKLAND, and TH. GUNNLAUGSSON. 1993. Sei whale abundance in the North Atlantic, estimated from NASS-87 and NASS-89 data. Rep. Int. Whal. Comm., 43: 315-321.

CHRISTENSEN, I. 1982. Killer whales in Norwegian Coastal Waters. Rep. Int. Whal. Comm., 32: 633642.

DESPORTES, G., and R. MOURITSEN. 1993. Preliminary results on the diet of long-finned pilot whales, Globicephala melas, around the Faroe Islands. Rep.
Int. Whal. Comm., (special issue) 14: 305-324.

EVANS, P. G. H. 1980. Cetaceans in British waters. Mammal Review, 10(1): 1-51.

FOLKOW, L. P., and A. S. BLIX. 1992. Metabolic rates of minke whales (Balaenoptera acutorostrata) in cold water. Acta Physiol. Scand, 145: 141-150.

GUNNLAUGSSON, TH., and J. SIGURJÓNSSON. 1990. NASS-87: Estimation of abundance of large cetaceans from observations made onboard Icelandic and Faroese surrey vessels. Rep. Int. Whal. Comm., 40: 571-580.

HAMMOND, P. S., S. HEIMLICH-BORAN, H. BENKE, P. BERGGREN, A. COLLET, M.P. HEIDEJØRGENSEN, and M. LEOPOLD. 1995. The distribution and abundance of harbour porpoises and other small cetaceans in the North Sea and adjacent waters. Rep. Int. Whal. Comm., 46: 675-676 (abstract).

HAUG, T., U. LINDSTR ØM, K. T. NILSSEN, I. RØTTINGEN, and H. J. SKAUG. 1996. Diet and food availability for Northeast Atlantic minke whales, Balaenoptera acutorostrata. Rep. Int. Whal. Comm., 46: 371-382.

HIBY, A. R., and P. S. HAMMOND. 1989. Survey techniques for estimating abundance of cetaceans. Rep. Int. Whal. Comm., (special issue) 11: 47-80.

HINGA, R. K. 1979. The food requirements of whales in the Southern Hemisphere. Deep Sea Research, 26A: 569-577.

HJORT, J., and J. T. RUUD. 1929. Whaling and fishing in the North Atlantic. ICES Rapp. Proc.-Verb., 56(1): $1-123$.

HORWOOD, J. W. 1990. Biology and exploitation of the minke whale. CRC Press, Boca Raton, Florida, $238 \mathrm{p}$.

ICHII, T., and H. KATO. 1991. Food and daily food consumption of southern minke whales in the Antarctic. Polar Biol., 11: 479-487.

INNES, S., D.M. LAVIGNE, W.M. EARLE, and K.M. KOVACS. 1986. Estimated feeding rates of marine mammals from heart mass to body mass ratios. Mar. Mam. Sci., 3(3): 227-229.

INNES, S., D. M. LAVIGNE. W. M. EARLE, and K. M. KOVACS. 1987. Feeding rates of seals and whales. J. Anim. Ecol., 56: $115-130$.

IWC (International Whaling Commission). 1986. Report of the workshop. Behaviour of whales in relation to management. In: G. P. Donovan (ed). Rep. Int. Whal. Comm., (special issue) 8: 1-36.

1993. Report of the Scientific Committee. Rep. Int. Whal. Comm., 43: 55-228.

JONSGÅRD, A. 1966. Biology of the North Atlantic fin whale Balaenoptera physalus (L). Taxonomy. distribution, migration and food. Hvalrådets Skr., 49: $1-62$.

1977. Norwegian and international regulations in the Norwegian whaling for minke whales. Balaenoptera acutorostrata, and small whales. Rep. Int. Whal. Comm., 27: 400-401. 
KATONA, S. K., S. A. TESTAVERDE, and B. BARR. 1978. Observations on a white-sided dolphin, Lagenorhynchus acutus, probably killed in gill nets in the Gulf of Maine. Fish. Bull., 76(2): 475-476.

KAWAMURA, A. 1974. Food and feeding ecology in the southern sei whale. Sci. Rep. Whales Res. Inst., Tokyo, 26: 25-144.

KENNEY, R. D., G. P. SCOTT, T. J. THOMPSON and H. E. WINN. 1997. Estimates of prey consumption and trophic impacts of cetaceans in the Northeast U.S. continental shelf ecosystem. J. Northw. Atl. Fish. Sci., 22: 155-171 (this volume).

KLEIBER, M. 1975. The fire of life - an introduction to animal energetics. R. E. Krieger Publ. Comp., Huntington, New York. 434 p.

LAVIGNE, D. M., S. INNES, G. A. J. WORTHY, K. M. KOVACS, O. J. SCHMITZ and J. P. HICKIE. 1986. Metabolic rates of seals and whales. Can. J. Zool., 64: 279-284.

LAWS, R. M. 1977. Seals and whales of the Southern Ocean. Phil. Trans. R. Soc. Lond B.: 81-89.

LAWS, R.M. 1985. The Ecology of the Southern Ocean. American Scientist, 73: 26-40.

LOCKYER, C. 1976. Body weights of some large whales. ICES J. Cons., 36: 259-273.

1977. Observations on diving behaviour of the sperm whale Physeter catodon. In: A Voyage of Discovery. M. Angel (ed.) Pergamon Press, Oxford: 591-609.

1981a. Growth and energy budgets of large baleen whales from the Southern Hemisphere. FAO Fish.Ser (3) (Mammals in the Seas 3): 379-487.

1981b. Estimation of the energy costs of growth, maintenance and reproduction in the female minke whale (Balaenoptera acutorostrata), from the southern hemisphere, south of $40^{\circ} \mathrm{S}$. Rep. Int. Whal.Comm., 31: 337-343.

1987a. Evaluation of the role of fat reserves in relation to the ecology of North Atlantic fin and sei whales. In: Approaches to Marine Mammal Energetics. A.C. Huntley, D. P. Costa. G. A. J. Worthy and M. A. Castellini (eds). Society for Marine Mammalogy Special Publication no 1: 183-203.

1987b. The relationship between body fat, food resource and reproductive energy costs in North Atlantic fin whales. Symp. Zool. Soc. Lond., 57: 343361.

MARKUSSEN, N. H., M. RYG, and C. LYDERSEN. 1992. Food consumption of the NE Atlantic minke whale (Balaenoptera acutorostrata) population estimated with a simulation model. ICES J. Mar. Sci., 49: 317-323.

MARTIN, A. R., and M. R. CLARKE. 1986. The diet of sperm whales (Physeter macrocephalus) captured between Iceland and Greenland. J. Mar. Biol. Assoc., U. K., 66: 779-790.

MITCHELL, E. 1973. Draft report on humpback whales taken under special scientific permit by eastern Canadian land stations, 1969-1971. Rep. Int.
Whal.Comm., 23: 138-154.

MITCHELL, E. 1975. Trophic relationships and competition for food in Northwest Atlantic whales. Proc. Can. Soc. Zool. Ann. Meet.: 123-133.

NAMMCO (North Atlantic Marine Mammal Commission). 1997. Report of the 5th Meeting of the Scientific Committee, Troms $\emptyset$, Norway, 10-14 March 1997, $105 \mathrm{p}$.

NORD ØY, E. S., L. P. FOLKOW, P.-E. MÅRTENSSON, and A. S. BLIX. 1995. Food requirements of Northeast Atlantic minke whales. In: Whales, seals, fish and man. A. Schytte-Blix. L. Walløe and Ø. Ulltang (eds). Elsevier Science B.V.: 361-369.

ØIEN, N. MS 1992. Estimates of $g(0)$ for harbour porpoise based on a survey in the North Sea in 1990. IWC Doc. SC/44/SM 7, 3 p.

OVERHOLTZ. W. J., S. A. MURAWSKI, and K. L. FOSTER. 1991. Impact of predatory fish, marine mammals, and seabirds on the pelagic fish ecosystem of the northeastern USA. In: Multispecies models relevant to management of living resources, N. Daan and M. P. Sissenwine (eds.). ICES Mar. Sci. Symp., 193: 198-208.

PALKA, D. 1995. Abundance estimate of the Gulf of Maine harbor porpoise. Rep. Int. Whal. Comm. (special issue) 16: 27-50.

POLACHECK, T. 1995. Double team field tests of line transect methods for shipboard sightings surveys for harbour porpoises. Rep. Int. Whal. Comm. (special issue) 16: 51-68.

RISTING, S. 1922. Av hvalfangstens historie. J. W. Cappelens Forlag, Kristiania. 631 .

SCOTT, G. P., R. D. KENNEY, T. J. THOMPSON. and H.E: WINN. 1983. Functional roles and ecological impacts of the cetacean community in the waters of the Northeastern U.S. continental shelf. ICES C.M. Doc., No. N:12. 33p.

SERGEANT, D.E. 1969. Feeding rates of Cetacea. Fiskeridir Skr. (Havunders.), 15: 246-258.

SERGEANT, D. E., D. J. ST. AUBIN, and J. R. GERACI 1980. Life history and Northwest Atlantic status of the Atlantic white-sided dolphin, Lagenorhynchus acutus. Cetology, 37: 1-12.

SIGURJÓNSSON, J. 1982. Icelandic minke whaling 1914-1980. Rep. Int. Whal. Comm., 32: 287-295.

1995. On the life history and autecology of North Atlantic rorquals. In: Whales, seals, fish and man. A. Schytte-Blix. L. Walløe and $\varnothing$. Ulltang (eds). Elsevier Science B.V.: 361-369.

SIGURJÓNSSON, J., and A. GALAN. 1991. Information on stomach contents of minke whales in Icelandic waters. Rep. Int. Whal. Comm., 41: 588 (abstract).

SIGURJÓNSSON, J., and TH. GUNNLAUGSSON. 1990. Recent trends in abundance of blue (Balaenoptera musculus) and humpback whales (Megaptera novaeangliae) off west and southwest Iceland with a note on occurrence of other cetacean species. Rep. Int. Whal. Comm., 40: 537-551. 
SIGURJÓNSSON, J., T. LYRHOLM, S. LEATHERWOOD, E. JÓNSSON, and G. VÍKINGSSON 1988. Photoidentification of killer whales, Orcinus orca, off Iceland, 1981 through 1986. Rit fiskideildar, 11: $99-114$.

SIGURJÓNSSON, J., TH. GUNNLAUGSSON, and M. PAYNE. 1989. NASS-87: Shipboard sightings surveys in Icelandic and adjacent waters June-July 1987. Rep. Int. Whal. Comm., 39: 395-409.

SIGURJÓNSSON, J., TH. GUNNLAUGSSON, P. ENSOR, M. NEWCOMER, and G. A. VÍKINGSSON. 1991. North Atlantic Sightings Survey 1989 (NASS89): Shipboard surveys in Icelandic and adjacent waters July August 1989. Rep. Int. Whal. Comm., 41: 559-572.

SIGURJÓNSSON, J., G. A. VÍKINGSSON, and C. LOCKYER. 1993. Two mass strandings of pilot whales (Globicephala melas) on the coast of Iceland. Rep. Int. Whal. Comm., (special issue) 14: $407-424$.

SIGURJÓNSSON, J., G. A. VÍKINGSSON, TH. GUNNLAUGSSON, and S.D. HALLDÓRSSON. MS 1996. North Atlantic Sightings Survey 1995 (NASS95): Shipboard surveys in Icelandic and adjacent waters June-July 1995. Preliminary cruise report. NAMMCO SC Doc. SC/4/18, 9 p.

STEFÁNSSON, G., J. SIGURJÓNSSON, and G. A. VÍKINGSSON. 1997. On dynamic interactions between some fish resources and cetaceans off Iceland based on a simulation model. J. Northw. Atl. Fish. Sci., 22: 357-370 (this volume).

STEIMLE, F. W. Jr., and R. J. TERRANOVA. 1985. Energy equivalents of marine organisms from the con- tinental shelf of the temperate Northwest Atlantic. J. Northw. Atl. Fish. Sci., 6: 117-124.

TOMILIN, 1967. Mammals of the USSR and adjacent countries. Vol. 9. Cetacea. Israel Program for Scientific Translations, V. G. Heptner (ed), Jerusalem.

VÍKINGSSON, G. A. 1990. Energetic studies on fin and sei whales caught off Iceland. Rep. int. Whal. Comm., 40: 365-373.

1995. Body condition of fin whales during summer off Iceland. In: Whales, seals, fish and man. A. Schytte-Blix. L. Walløe and $\varnothing$. Ulltang (eds). Elsevier Science B.V.: 361-369.

1997. Feeding of fin whales (Balaenoptera physalus) off Iceland - diurnal and seasonal variation and possible rates. J. Northw. Atl. Fish. Sci., 22: 77-89 (this volume).

VÍKINGSSON, G. A and J. SIGURJÓNSSON. MS 1996. Feeding studies on the harbour porpoise (Phocoena phocoena) in Icelandic coastal waters. ICES C.M. Doc., No. N:7, 19 p.

VÍKINGSSON. G., J. SIGURJÓNSSON, and TH. GUNNLAUGSSON. 1988. On the relationship between weight. length and girth dimensions in fin and sei whales caught off Iceland. Rep. Int. Whal. Comm., 38: 323-326.

WATSON, L. 1981. Sea guide to Whales of the World. Hutchinson, London, 302 p.

YOCHEM, P. K., and S. LEATHERWOOD. 1985. Blue whales Balaenoptera musculus (Linnaeus, 1758). In: Handbook of Marine Mammals. Vol. 3. The Sirenias and Baleen Whales. S. H. Ridgway, and R. J. Harrison (eds). Academic Press, London: 193-240. 